\section{ECONOMICS}

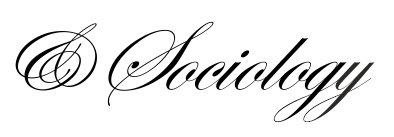

Wasiluk, A., \& Ginevičius, R. (2020). Pro-innovative motives for establishing cooperation by enterprises: An empirical study in Poland. Economics and Sociology, 13(2), 258-278. doi:10.14254/2071-789X.2020/13-2/17

\title{
PRO-INNOVATIVE MOTIVES FOR ESTABLISHING COOPERATION BY ENTERPRISES: AN EMPIRICAL STUDY IN POLAND
}

\begin{abstract}
Anna Wasiluk
Bialystok University of Technology,

Poland

E-mail:a.wasiluk@pb.edu.pl

ORCID 0000-0002-5980-333X

Romualdas Ginevičius

Bialystok. University of Technology, Poland

E-mail:

romualdas.ginevicius@vgtu.lt

ORCID 0000-0003-2067-4398
\end{abstract}

Received: October, 2019

1st Revision: January, 2020

Accepted: June, 2020

DOI: $10.14254 / 2071-$

789X.2020/13-2/17
ABSTRACT. The issue of innovation is currently often perceived in the context of inter-organizational cooperation. In literature on this subject one of the ways to win in competition is by seeking synergies resulting from cooperation of companies with other firms, including their competitors, as well as with business environment institutions or research and development entities. The global experience indicates an important role of these ties in generating innovations. Taking all of the above into account, this paper aims to determine whether companies establish cooperation with one another and also with other institutions of their business environment and science, and whether they are ready to strengthen cooperation in the near future in order to improve their innovativeness. Quantitative research included 76 construction companies, 83 food industry enterprises, 76 enterprises in metal and machinery and 82 those in wood and furniture industry. The research carried out has allowed us to specify previous academic achievements with regard to the readiness of companies to undertake cooperation with their competition, with scientific institutions and also with other business environment entities. The obtained results indicate a large deficit both in terms of previous cooperation and with regard to the readiness to increase it in the near future, which, unfortunately, confirms previous conclusions outlined in the already available literature.

Keywords: companies, business environment institutions,

JEL Classification: L22, L26, M14

\section{Introduction}

The issue of innovation, viewed nowadays as a necessity (Kirikkaleli, \& Ozun, 2019), a fundament of intelligent choice and one of the key factors in building a competitive advantage for both individual entities (Hao, Qi, Gong, Chen, \& Shen, 2019) and entire regions (Tidd, \& Bessant, 2013, pp. 3-5), is often perceived in the context of inter-companies cooperation (Kijkuit, \& van den Ende, 2010) and having a positive effect on the latter (Daniluk, 2018; Karbowski, 2019). This approach is evident, among others, in the concept of the triple helix, which assumes cooperation of business, science and governmental institutions (Cai, 2015). Polish publications on the topic of innovation indicate, apart from the necessary 
cooperation between these three areas, the important role of business environment institutions as those which facilitate contact and the flow of information, particularly between the areas of business and science (Daniluk, \& Tomaszuk, 2016). Literature on the subject underlines that one of the ways of opposing increased competition from international economic structures (Nguyen, Larimo, \& Wang, 2019) is by finding a synergy effect resulting from cooperation of businesses both with other firms (Kim, Dinwoodie, \& Seo, 2018; Raišienè et al., 2019), including competing ones (Antonelli, 1992) and with business environment institutions (Daniluk, 2016) and/or research institutions (Lin, Hsiao, \& Lin, 2013; Vaiciukevičiūtè, Stankevičienè, \& Bratčikovienè, 2019). Practical experience from around the globe indicates the importance of these ties in generating innovations. Quantity and especially quality of the relations between them play a crucial role in increasing the competitiveness of both firms (Rzepka, 2019) and entire regions (Garanti, \& Zvirbule-Berezina, 2013).

The need to strengthen inter-organisational cooperation is evident in the assumptions of many European and governmental programs, which result in a multitude of initiatives directed at building cooperation between various organisations, e.g., networking and clusters (European Commission, 2010). It should be noted that authors writing on this subject matter often point to the pro-innovative character of these structures (Hemert, Nijkamp, \& Masurel, 2012). It is generally accepted that contemporary economy is characterised by networks, and links of this kind, both formal or informal, penetrate all areas of the economy. Moreover, literature also underlines the importance of the quality of ties/relations rather than their number (Czakon, 2012). A strong network of internal and external entities, alongside technical and social infrastructure and well-functioning strategic management, is one of the factors preconditioning international competitiveness (Gorynia, \& Jankowska, 2008; Lis, 2018; Elexa, Lesáková, Klementová, \& Klement, 2019).

\section{Literature review}

A noticeable tendency of the last decades is the shift of businesses from a confrontational orientation in the direction of a more peaceful and collaborative approach towards fulfilling their objectives (Nazarko, \& Chodakowska, 2017). Many business leaders began to notice that as they themselves did not possess all the necessary resources, operations carried out autonomously and independently were often set up to fail (eg Schermerhorn, 1975), at the same time, value-oriented business administration is determined by overall business environment (Lašáková et al., 2019). The validity of this action is confirmed by the results of numerous studies, which indicate that cooperation brings tangible benefits (Czakon, 2007; Nazarko, 2013; Kozłowski, \& Matejun, 2012; Rzepka, 2017) These advantages appear regardless of whether cooperation is formal or informal (Stańczyk-Hugiet, \& Strzelecka, 2015; Lis, 2019).

This does not mean, however, that cooperation always solely brings advantages and ends in success. As pointed out by P. Kale, J.H. Dyer and H. Singh (2002) a significant percentage of inter-organisational cooperation ends in a fiasco, and ties are severed before objectives have been fulfilled. It is often the case that ties between the cooperating entities are weak, unstable and most importantly characterised by an attempt to take advantage of one's partner (Moczydłowska, Korombel, \& Bitkowska, 2017). Studies regarding the conditions of cooperation therefore take on an important role, especially those touching on the limits, shortcomings and weaknesses of cooperation (Stein, \& Ginevičius 2010; Nowak, 2015).

Among the barriers of initiating cooperation, subject literature lists: fear of an excessive dependency on one's partner, loss of identity, knowledge and competitiveness, excessive involvement in relations and an uncertainty of the amount and change in expenditure in order to maintain relations (Adler, \& Kwon 2014). Many authors underline 
that the most significant, even key, barrier to undertaking cooperation is that of human capital (Fawcett, Magnan, \& McCarter, 2008), most notably a lack of trust towards new partners (Dobrzyński, Dziekoński, \& Jurczuk, 2013; Wasiluk, 2015; Oláh et al., 2017) or traditional attitudes towards some essential features of human capital (Bilan et al., 2017). Researchers point out the existence of mental barriers in the business sector, characterised by mistrust towards other businesses (Wasiluk, 2013; Ryciuk, 2016), but also towards entities in the science sphere (Wasiluk, 2016) and business environment institutions (Stanisławski, 2016). Subject literature also draws attention to the fact that there are often misunderstandings, conflicts and antagonisms between businesses (Leonidou, Barnes, \& Talias, 2006). Irregularities and abnormalities with which businesses are met in the market cause them to act in a careful and cautious manner, even at the cost of lower profits (Nowak, 2015).

Cooperation in the innovation sector both in the form of a value chain and in the form of competence type increases the innovative efficiency of companies (Chick, Huchzermeier, \& Netessine, 2014; Bilan et al., 2019), and cooperative relations are nowadays regarded as a specific type of resource (Widelska, Michalczuk, \& Moczydłowska, 2014). Studies from around the globe have shown that new conceptions of innovative processes or products are not only a result of business operations, which constitute the last stage of the value chain, but of an improvement in the flow of information and cooperation between partners (Roy, Sivaramakrishnan, \& Wilkinson, 2004; Myšková \& Kuběnka, 2019). For this reason, a significant and current area of discourse in subject literature is the cooperation of businesses (Stańczyk-Hugiet, \& Strzelecka, 2015). As studies show, over 50\% of cooperative relations are formed between entities within the same sector or competitors (Gnyawali, \& Park, 2009) (in Poland $49 \%$ of industrial enterprises cooperate with firms of the same sector, and $44 \%$ with firms of related sectors - eg. KPMG, 2014), and decidedly less often between business environment institutions or scientific institutions, regardless of the fact that these are immensely valuable (Zeng, 2010). They stimulate the increase in the competitiveness of companies, with an increased intensity of agreements on innovation with various entities having a positive impact on the proportion of profits from innovative operations within the total profits in the given sector (Wojnicka, 2004). There is no doubt that science and its surroundings breed innovative ideas, which are then transferred to businesses. Nevertheless, in Poland, despite the creation of two government programs providing public funding intended for the development of both basic and applied studies, there have been no significant advances in development of science and the supply of innovation. Previous Polish attempts at commercialising innovation have so far also proven ineffective (Romanowska, 2016). The results of the analysis of innovation of businesses in Poland still confirm the thesis of low (it seems that this problem concerns not only Poland but also its neighboring countries - e.g. Adekola, Korsakiene, \& Tvaronavičiene, 2008), even steadily decreasing levels of innovation in business (Gryczka, 2017; Braumberger, 2019). The results of the analysis of innovation of businesses in Poland still confirm the thesis of low, even steadily decreasing levels of innovation in business.

\section{Methodological approach}

Taking into account the above considerations relevant to the author of this paper was to determine whether the competing companies, will cooperate with both one another andthe institutions of business environment and science, and whether they are ready to strengthen cooperation in the near future in order to improve their innovativeness. A picture of the current state and future perspective should help largely determine the prospects for the creation and development of a variety of network relations, including clusters. 
Bearing in mind the objective set, a research problem was formulated in the form of the following questions:

1. What is the declared level of cooperation of the surveyed companies with competition and business environment and scientific institutions?

2. What is the interest of the surveyed companies in strengthening cooperation with the competition and business environment and scientific institutions in the near future?

3. To what extent do the identified, pro-innovation factors affect the current level of cooperation of the surveyed companies with competition and business environment and scientific institutions?

4. To what extent may the positive changes in the identified, pro-innovation factors contribute to the improvement of the cooperation of the surveyed companies with competition and business environment and scientific institutions in the near future?

5. Is there a correlation between the ratings of the various, pro-innovation factors impact on the present cooperation and the ratings of possibilities for improving it in the future?

6. Is there a dependency in the ratings of the existing cooperation between the different spheres (competition, scientific institutions and business environment institutions)?

7. Is there a dependency in the ratings of interest in strengthening cooperation between the different spheres (competition, scientific institutions and business environment institutions) in the near future?

The analyses presented in this text are based on the results of broad research in which one of the authors of this paper was a member of the research team (Polish - Belarusian joint research project for years 2014-2016 „Readiness of enterprises to create cross-border networking" under the agreement on scientific cooperation between The Polish Academy of Sciences and The Belarusian National Academy of Sciences). The analyses included companies in construction (C), food (F), metal and machine (M), wood and furniture (WF) industrys as priority areas for development of the Podlaskie region (UMWP 2013). The sources for selection of entities to participate in the research were various databases, including those obtained from the Regional Statistical Office. Some respondents were obtained through the use of a snowball procedure based on recommendation of certain entities by other study participants. The quantitative research included the total of 381 companies - 76 construction and 305 industrial, therein 83 in food industry, 76 in metal and machinery and 82 in wood and furniture industry based in the area of Podlaskie region.

For the purposes of the carried out research the classification of business environment institutions was adopted in accordance with the recommendation of the Polish Agency for Enterprise Development (Bąkowski, \& Mażewska, 2015, pp. 7-8). The identification of factors affecting the establishment of cooperation was based on a critical analysis of domestic and foreign literature, conducted surveys, and was also the result of discussions with experts from both academic society and business.

The questionnaire to be filled in was addressed to the owners of companies or members of senior management. Respondents assessed the phenomenon in a seven-grade scale, where 1 meant a complete lack of influence or a complete lack of cooperation and 7 - a very large impact or very good cooperation.

The collected empirical material has been encoded and then subjected to conversion to numerical form, which allowed to carry out detailed analyses of the surveyed group. The following statistical measures were used to interpret the research results: measures of dispersion - the coefficient of variation and measures of central tendency - mean, median, dominant. To indicate the strength of interdependence between the ratings a coefficient of Spearman correlation rank was used and then t-Student test to examine its significance. To identify statistically significant differences in the ratings among sectors the Kruskal-Wallis 
test was used. Statistical calculations were made with the use of STATISTICA programme version 13.1 .

\section{Conducting research and results}

\subsection{Cooperation of enterprises with competition}

Respondents from the analysed sectors assessed the level of existing cooperation between their companies and competitors very poorly and although the average scores for individual sectors differ a little from each other, the conducted Kruskal-Wallis test indicated that the differences are statistically insignificant (see Table 1). In all groups of the surveyed companies we are dealing with a wide diversity of the respondents' ratings, although in the case of wood and furniture companies it is somewhat stronger. Little optimism is also seen in assessing the degree of the studied companies' interest in cooperation with competitors in the next 2-3 years. The declared willingness to establish such cooperation differs slightly from the current situation. Conducted Spearman' ranks correlation indicates a high dependency between the ratings of current cooperation and the possibility of increasing it in the near future. The higher the surveyed companies assessed the current level of their cooperation with competition, the higher the level of readiness to strengthen it in the future indicated in their declarations.

Table 1. Current and future cooperation with competitors in the respondents' opinion

\begin{tabular}{|c|c|c|c|c|}
\hline Specification & $\bar{x}$ & $M_{e}$ & $D$ & $V$ \\
\hline \multicolumn{5}{|c|}{$\begin{array}{r}\text { Declared level of cooperation with competitors/ Degree of interest in strengthening cooperation within } \\
\text { the next 2-3 years }\end{array}$} \\
\hline Companies in total & $2.80 / 3.01$ & $3.00 / 3.00$ & $2 / 3$ & $51.91 / 50.20$ \\
\hline Food companies & $2.78 / 3.02$ & $3.00 / 3.00$ & $1 ; 3 / 3$ & $49.25 / 43.51$ \\
\hline Metal and machine companies & $2.89 / 3.04$ & $3.00 / 3.00$ & $3 / 3$ & $50.64 / 51.93$ \\
\hline Wood and furniture companies & $2.83 / 2.94$ & $2.50 / 3.00$ & $1 / 3$ & $57.93 / 54.61$ \\
\hline Construction companies & $2.67 / 2.89$ & $2.00 / 3.00$ & $2 / 2$ & $47.11 / 49.04$ \\
\hline \multicolumn{5}{|c|}{ Correlation of Spearman's rank $(\mathrm{p}<0.05)$} \\
\hline \multicolumn{5}{|c|}{ Assessment of the current level of cooperation and possibilities of its strengthening in the future. } \\
\hline Companies in total & & & & .653550 \\
\hline Food companies & & & & .600907 \\
\hline Metal and machine companies & & & & .677531 \\
\hline Wood and furniture companies & & & & .645989 \\
\hline Construction companies & & & & .626617 \\
\hline \multicolumn{5}{|c|}{ Kruskal-Wallis test $(\mathrm{p}<0.05)}$. \\
\hline & & $\mathrm{H}$ & & $\mathrm{p}$ \\
\hline Declared level of cooperation $\mathrm{w}$ & & .8219888 & & .8442 \\
\hline $\begin{array}{l}\text { Degree of interest in strengtheni } \\
\text { within the next 2-3 years }\end{array}$ & & 1.039392 & & .7917 \\
\hline
\end{tabular}

Source: own study

All pro-innovative reasons assessed by the respondents make a weak contribution to establishing their cooperation with competition (see Table 2). The activities aimed at improving the quality of products or services have biggest impact on it, while the possibility of joint research and development projects has the smallest one. Although there are slight differences in the average ratings of the impact of the various conditions in the analyzed 
sectors the conducted Kruskal-Wallis test indicates no statistically significant differences between them. There is a high diversity in the respondents' ratings in individual sectors when assessing the impact of various factors on the establishment of cooperation with the competition.

Table 2. Descriptive statistics for the ratings of the impact of various factors on the level of existing cooperation with competitors and of positive changes in various factors on the level of cooperation in the near future

\begin{tabular}{|c|c|c|c|c|c|}
\hline Specification & $\bar{x}$ & $M_{e}$ & $D$ & $\mathrm{Sr}_{\mathrm{r}}$ & $\begin{array}{l}\text { pearman's rank } \\
(p<0.05)\end{array}$ \\
\hline \multicolumn{6}{|c|}{$\begin{array}{l}\text { Companies in total } \\
\text { Food companies } \\
\text { Metal and machine companies } \\
\text { Wood and furniture companies } \\
\text { Construction companies }\end{array}$} \\
\hline $\begin{array}{l}\text { rise of innovation } \\
\text { potential (faster } \\
\text { generating and } \\
\text { implementing of products } \\
\text { and technology } \\
\text { innovations) }\end{array}$ & $\begin{array}{l}2.80 / 3.41 \\
2.96 / 3.49 \\
2.67 / 3.18 \\
2.85 / 3.57 \\
2.67 / 3.16\end{array}$ & $\begin{array}{l}3.00 / 4.00 \\
3.00 / 4.00 \\
2.00 / 3.00 \\
3.00 / 4.00 \\
3.00 / 3.00\end{array}$ & $\begin{array}{l}1 / 4 \\
1 / 4 \\
1 / 1 \\
1 / 5 \\
1 / 4\end{array}$ & $\begin{array}{l}59.62 / 52.70 \\
54.62 / 49.24 \\
62.76 / 57.96 \\
60.10 / 49.95 \\
62.16 / 53.50\end{array}$ & $\begin{array}{l}\frac{.652414}{.648516} \\
\frac{.747349}{.581987} \\
.615545 \\
\end{array}$ \\
\hline $\begin{array}{l}\text { products/services quality } \\
\text { improvement }\end{array}$ & $\begin{array}{l}3.09 / 3.52 \\
3.16 / 3.53 \\
3.09 / 3.47 \\
3.24 / 3.98 \\
3.16 / 3.30 \\
\end{array}$ & $\begin{array}{l}3.00 / 3.00 \\
3.00 / 4.00 \\
3.00 / 3.50 \\
3.00 / 4.00 \\
3.00 / 3.00 \\
\end{array}$ & $\begin{array}{c}1 / 1 \\
1 / 3 \\
1 / 1 \\
1 ; 3 / 6 \\
1 / 1 \\
\end{array}$ & $\begin{array}{l}57.64 / 53.33 \\
52.00 / 48.53 \\
56.18 / 56.11 \\
55.56 / 46.26 \\
63.34 / 58.71 \\
\end{array}$ & $\begin{array}{l}.663178 \\
.638370 \\
.668037 \\
.580500 \\
.726009 \\
\end{array}$ \\
\hline $\begin{array}{l}\text { possibility of } \\
\text { implementation of joint } \\
\text { investment projects (e.g. } \\
\text { joint purchase of } \\
\text { expensive technologies, } \\
\text { equipment, etc.) }\end{array}$ & $\begin{array}{l}2.72 / 3.28 \\
2.80 / 3.20 \\
2.58 / 3.04 \\
2.65 / 3.38 \\
2.82 / 3.45\end{array}$ & $\begin{array}{l}2.00 / 3.00 \\
2.00 / 3.00 \\
2.00 / 3.00 \\
2.00 / 3.00 \\
2.00 / 3.00\end{array}$ & $\begin{array}{c}1 / 1 \\
1 / 3 \\
1 / 1 \\
1 / 1 \\
1 / 1 ; 3\end{array}$ & $\begin{array}{l}66.22 / 55.95 \\
64.86 / 51.98 \\
71.15 / 64.57 \\
65.95 / 52.76 \\
63.72 / 55.11\end{array}$ & $\begin{array}{l}\frac{.627716}{.639489} \\
\frac{.672434}{.523889} \\
.608806 \\
\end{array}$ \\
\hline $\begin{array}{l}\text { possibilities of } \\
\text { implementation of joint } \\
\text { research and development } \\
\text { activities }\end{array}$ & $\begin{array}{l}2.59 / 3.14 \\
2.60 / 2.95 \\
2.57 / 3.07 \\
2.50 / 3.11 \\
2.51 / 3.21 \\
\end{array}$ & $\begin{array}{l}2.00 / 3.00 \\
2.00 / 3.00 \\
2.00 / 2.00 \\
2.00 / 3.00 \\
2.00 / 3.00 \\
\end{array}$ & $\begin{array}{c}1 / 1 \\
1 / 1 \\
1 / 1 \\
1 / 1 ; 3 \\
1 / 1 \\
\end{array}$ & $\begin{array}{l}63.86 / 56.22 \\
62.06 / 54.96 \\
66.24 / 64.87 \\
61.02 / 51.53 \\
65.14 / 56.02 \\
\end{array}$ & $\begin{array}{l}\frac{.639891}{.570179} \\
.614060 \\
.644771 \\
.712789 \\
\end{array}$ \\
\hline \multicolumn{6}{|c|}{ Kruskal-Wallis test $(\mathrm{p}<0.05)$} \\
\hline rise of innovation potential & & $\begin{array}{c}\mathrm{H} \\
2.298173\end{array}$ & & $\begin{array}{c}\mathrm{H} \\
3.717109\end{array}$ & $\begin{array}{c}\mathrm{p} \\
.2937\end{array}$ \\
\hline products/services quality in & rovement & .367517 & & 5.961475 & .1135 \\
\hline $\begin{array}{l}\text { possibility of implementati } \\
\text { investment projects }\end{array}$ & of joint & 1.334577 & & 2.525200 & .4708 \\
\hline $\begin{array}{l}\text { possibilities of implementa } \\
\text { research and development }\end{array}$ & $\begin{array}{l}\text { n of joint } \\
\text { tivities }\end{array}$ & .148658 & & .9969672 & .8020 \\
\hline
\end{tabular}

Source: own study

Pro-innovative reasons were a rare reason for establishing cooperation with competitors. Similar conclusions were reached also by other researchers. Polish publications on the innovativeness of companies (eg.: Baczko, 2012; PARP, 2015; Wasiluk, 2017) notice that Polish companies in general rarely undertake to carry out research and development activities and expenditures on innovation activities are intended mostly for the purchase of 
machinery and equipment (Bromski, 2013). Studies by the Central Statistical Office (GUS 2015, pp. 97-110; GUS 2018, pp. 81-92) confirm that the disability of Polish companies to cooperate with various actors in the implementation of innovative projects is their weakness. In 2012-2014 in the field of innovation activities only $30.1 \%$ of industrial enterprises cooperated (in the years 2015-2017-28.7\%), and in the framework of cluster initiatives only $13,7 \%$ (in the years $2015-2017$ increased to $20 \%$ ). The research presented by A.M. Kowalski (2010) indicates that the positive impact of cooperation within clusters on the number of innovations implemented by the company was noticed by $35 \%$ of the surveyed business entities and the most common were marketing innovations. The least frequent innovations introduced by enterprises in connection with the operation of the clusters were process/technological innovations. The researchers indicate also that the main incentive to initiate cooperation between enterprises is to raise funds (Un, Romero-Martinez, \& MontoroSanchez, 2009; Klimas, 2015).

In the respondents' opinion positive changes in terms of opportunities for cooperation in order to improve the quality of products or provided services contributed to the improvement of cooperation with competition to the greatest extent. Little effect on it as assessed by the respondents from the food industry and the wood and furniture industry would have the positive changes in the area of possibility of implementation of joint research and development projects, in the case of metal and machine companies - the possibility of implementation of joint investment projects such as for example the joint purchase of technology or equipment and in the case of construction companies - a rise in innovation potential. The Kruskal-Wallis test indicates no statistically significant differences between sectors in their ratings. An analysis of the coefficient of variation allows us to determine the presence of a strong differentiation in the ratings of respondents in the same sector.

There is a positive correlation between the ratings of the impact of various factors on existing cooperation and the evaluation of possibilities for improving it in the future in the case of respondents across all sectors. Spearman's rank correlation leads to the conclusion that the increase of ratings of the impact of individual factors on the current level of cooperation is accompanied by an increase in the average value of the ratings of the impact of positive changes in these factors on the establishment of cooperation in the future. In most cases, we can talk about a high strength of correlations.

\subsection{Cooperation of companies with business environment institutions}

Respondents assessed the level of existing cooperation between their companies and business environment institutions (see Table 3) as low, although the average scores for individual sectors differ a little from each other, the conducted Kruskal-Wallis test indicated that the differences are statistically significant only in the case of the opinions of food companies and wood and furniture companies opinions. In the wood and furniture industry and construction industry the majority of the analyzed companies said that no cooperation has been established with these institutions so far (dominant level 1). In the case of all groups of surveyed companies we are dealing with a strong differentiation of respondents ratings.

Low interest in cooperation of companies with business environment institutions is also indicated by other researchers in their works (Zeng, Xie, \& Tam, 2010). J. Różański (2016) reports that only $1.1 \%$ of the enterprises surveyed by him declared frequent contacts with technology transfer centres, technology or industrial parks. Data from the Central Statistical Office data show, however, that only a little over 5\% of industrial enterprises indicated cooperation with these institutions as particularly advantageous (GUS 2015, p. 104) (in 2015-2017 - 7.9\%, while this indicator also includes commercial laboratories and private R\&D institutions, which were not included jointly in previous years (GUS 2018, p. 87). It 
seems that this may be one reason for the low interest of companies in establishing cooperation.

Slightly greater optimism in regard to cooperation with business environment institutions is noticeable in the respondents' declarations regarding the near future. Average ratings in various sectors differ a little from each other; however, as indicated by the KruskalWallis test these differences are not statistically significant. Although the diversity of ratings is lower than in the case of current cooperation, it still remains at a high level. In addition, the conducted Spearman correlation rank indicates a moderate (in the case of food industry) or even high (in the case of the other sectors) dependency of the ratings of current cooperation on possibilities of strengthening it in the next 2-3 years. The higher the respondents assessed the current level of their cooperation with these entities, the higher the readiness to strengthen it in the future was declared. This may be due either to a growing awareness of the surveyed companies about the benefits of such cooperation, the challenges posed by the environment or the experience of such cooperation in the past.

Table 3. Current and future cooperation with competitors in the respondents' opinion

\begin{tabular}{|c|c|c|c|c|}
\hline Specification & $\bar{x}$ & $M_{e}$ & $D$ & $V$ \\
\hline \multicolumn{5}{|c|}{$\begin{array}{r}\text { Declared level of cooperation with business environment institutions / Degree of interest in } \\
\text { strengthening cooperation within the next 2-3 years }\end{array}$} \\
\hline Companies in total & $3.07 / 3.69$ & $3.00 / 4.00$ & $3 / 4$ & $49.88 / 43.50$ \\
\hline Food companies & $3.42 / 3.64$ & $3.00 / 4.00$ & $3 / 4$ & $41.61 / 43.68$ \\
\hline Metal and machine companies & $3.09 / 3.97$ & $3.00 / 4.00$ & $3 / 3 ; 5$ & $49.59 / 41.29$ \\
\hline Wood and furniture companies & $2.77 / 3.41$ & $3.00 / 3.00$ & $1 / 3$ & $52.12 / 49.55$ \\
\hline Construction companies & $2.84 / 3.68$ & $3.00 / 4.00$ & $1 / 3$ & $53.61 / 40.43$ \\
\hline \multicolumn{5}{|c|}{ Correlation of Spearman's rank $(\mathrm{p}<0.05)$} \\
\hline \multicolumn{5}{|c|}{ Rating of the current level of cooperation and possibilities of its strengthening in the future. } \\
\hline Companies in total & & & & 644566 \\
\hline Food companies & & & & 550189 \\
\hline Metal and machine companies & & & & 670404 \\
\hline Wood and furniture companies & & & & .724251 \\
\hline Construction companies & & & & 630760 \\
\hline \multicolumn{5}{|c|}{ Kruskal-Wallis test $(\mathrm{p}<0.05)$} \\
\hline & & $\mathrm{H}$ & & $\mathrm{p}$ \\
\hline $\begin{array}{l}\text { Declared level of cooperation with business } \\
\text { environment institutions }\end{array}$ & & $\begin{array}{c}10.13714 \\
\mathrm{WF} / \mathrm{F} .029861\end{array}$ & & .0174 \\
\hline $\begin{array}{l}\text { Degree of interest in strengthening cooperati } \\
\text { within the next } 2-3 \text { years }\end{array}$ & & 4.529715 & & .2097 \\
\hline
\end{tabular}

Source: own study

The pro-innovative reasons analysed in this text were not in the respondents' opinion the primary ones to undertake cooperation with business environment institutions (see Table 4). They contributed establishing contacts between the two spheres of economic life only to a small degree. For the majority of sectors the dominant remained at level 1 which proves that the highest percentage of respondents have never undertaken any cooperation in this area. The most active in cooperation with business environment institutions were food companies and metal and machine companies, while the most frequent reason was the possibility to get aid in the transfer of technology. There were no statistically significant differences between the analysed sectors in their ratings of reasons. 
Table 4. Descriptive statistics for the ratings of the impact of various factors on the level of existing cooperation with business environment institutions and of positive changes in various factors on the level of cooperation in the near future

\begin{tabular}{|c|c|c|c|c|c|}
\hline Specification & $\bar{x}$ & $M_{e}$ & $D$ & $V$ & $\begin{array}{c}\text { Spearman's } \\
\text { rank } \\
(\mathrm{p}<0.05)\end{array}$ \\
\hline \multicolumn{6}{|c|}{$\begin{array}{l}\text { Companies in total } \\
\text { Food companies } \\
\text { Metal and machine companies } \\
\text { Wood and furniture companies } \\
\text { Construction companies }\end{array}$} \\
\hline $\begin{array}{l}\text { possibilities of } \\
\text { implementation of joint } \\
\text { research and development } \\
\text { initiatives }\end{array}$ & $\begin{array}{l}3.01 / 3.70 \\
3.05 / 3.60 \\
3.13 / 4.04 \\
2.73 / 3.39 \\
2.95 / 3.62\end{array}$ & $\begin{array}{l}3.00 / 4.00 \\
3.00 / 4.00 \\
3.00 / 4.00 \\
2.50 / 3.00 \\
2.50 / 3.50\end{array}$ & $\begin{array}{l}1 / 4 \\
2 / 5 \\
3 / 3 \\
1 / 2 \\
1 / 2\end{array}$ & $\begin{array}{l}57.41 / 49.74 \\
55.87 / 47.48 \\
51.97 / 45.28 \\
57.54 / 53.80 \\
59.90 / 49.64\end{array}$ & $\begin{array}{l}.722554 \\
.728707 \\
.603880 \\
.670122 \\
.771040 \\
\end{array}$ \\
\hline $\begin{array}{l}\text { access to research } \\
\text { centres/research } \\
\text { infrastructure }\end{array}$ & $\begin{array}{l}3.04 / 3.69 \\
3.28 / 3.61 \\
3.25 / 4.11 \\
2.65 / 3.53 \\
2.80 / 3.41\end{array}$ & $\begin{array}{l}3.00 / 4.00 \\
3.00 / 4.00 \\
3.00 / 4.00 \\
2.00 / 3.00 \\
2.50 / 3.00\end{array}$ & $\begin{array}{c}1 / 4 \\
1 / 4 \\
3 / 5 \\
1 / 1 ; 4 \\
1 / 3 \\
\end{array}$ & $\begin{array}{l}57.44 / 48.02 \\
54.19 / 46.10 \\
50.28 / 40.29 \\
61.24 / 53.91 \\
58.56 / 49.84 \\
\end{array}$ & $\begin{array}{l}\frac{.690034}{.618498} \\
\frac{.640082}{.670468} \\
.719948 \\
\end{array}$ \\
\hline $\begin{array}{l}\text { commercilisation of } \\
\text { research results }\end{array}$ & $\begin{array}{l}2.86 / 3.40 \\
3.13 / 3.52 \\
3.01 / 3.43 \\
2.66 / 3.28 \\
2.76 / 3.43 \\
\end{array}$ & $\begin{array}{l}3.00 / 3.00 \\
3.00 / 4.00 \\
3.00 / 3.00 \\
3.00 / 2.00 \\
3.00 / 3.00 \\
\end{array}$ & $\begin{array}{l}1 / 4 \\
3 / 4 \\
3 / 3 \\
1 / 1 \\
1 / 4\end{array}$ & $\begin{array}{l}55.95 / 50.39 \\
50.54 / 45.57 \\
50.40 / 47.15 \\
57.68 / 65.95 \\
59.35 / 53.18 \\
\end{array}$ & $\begin{array}{l}. .689117 \\
.704789 \\
.615248 \\
.674559 \\
.646103 \\
\end{array}$ \\
\hline $\begin{array}{l}\text { help with transfer of } \\
\text { technology }\end{array}$ & $\begin{array}{l}3.40 / 3.99 \\
3.58 / 4.08 \\
3.45 / 3.88 \\
3.27 / 3.96 \\
3.09 / 3.88 \\
\end{array}$ & $\begin{array}{l}3.00 / 4.00 \\
4.00 / 4.00 \\
3.00 / 4.00 \\
3.00 / 4.00 \\
3.00 / 4.00 \\
\end{array}$ & $\begin{array}{l}1 / 4 \\
4 / 5 \\
3 / 4 \\
1 / 4 \\
1 / 4 \\
\end{array}$ & $\begin{array}{l}53.09 / 44.00 \\
45.80 / 41.92 \\
54.09 / 45.89 \\
53.98 / 43.51 \\
56.18 / 44.52\end{array}$ & $\begin{array}{l}\frac{.681178}{.667024} \\
\frac{.669412}{.645785} \\
.644284 \\
\end{array}$ \\
\hline \multicolumn{6}{|c|}{ Kruskal-Wallis test $(\mathrm{p}<.05)$} \\
\hline $\begin{array}{l}\text { possibilities of implementa } \\
\text { research and development }\end{array}$ & $\begin{array}{l}1 \text { of joint } \\
\text { iatives }\end{array}$ & 2.632104 & .4519 & 5.122168 & .1631 \\
\hline $\begin{array}{l}\text { access to research centres } / \mathrm{r} \\
\text { infrastructure }\end{array}$ & arch & 8.918325 & .0304 & $\begin{array}{c}9.701322 \\
\text { WF/M .036128 } \\
\end{array}$ & .0213 \\
\hline commercilisation of resear & esults & 5.245654 & .1547 & 1.234965 & .7446 \\
\hline help with transfer of technc & & 3.637536 & .3034 & .8600864 & .8350 \\
\hline
\end{tabular}

Source: own study

In the opinion of respondents positive changes, especially with respect to help in the transfer of technology, would influence the improvement of companies' cooperation with business environment institutions to the greatest extent. Improved possibilities for the implementation of joint research and development projects and easier access to facilities or research infrastructure would also be significant. A positive change in helping to commercialise research would have a relatively smaller impact on it. This seems to be due to the fact that, as mentioned earlier, Polish companies rarely undertake to carry out research and development and if they do it is only for their own needs. In cooperation with the science entities the direct contact is usually preferred, without any entities acting as intermediaries. The Kruskal-Wallis test indicates the presence of statistically significant differences only 
between the opinions of wood and furniture and metal and machine companies in the respect of impact of positive changes in access to facilities and research infrastructure. The analysis of the variation coefficient allowed determining the existence of a strong differentiation of respondents' ratings in the same sector.

There was a positive correlation between the ratings of influence of various reasons on the respondents' existing cooperation with the institutions of business environment and theratings of possibilities for improving it in the future in case of occurrence of positive changes in these areas. Spearman's rank correlation leads to the conclusion that the increase in the ratings of the level of individual factors impact on the current level of cooperation is accompanied by an increase in the average values of the ratings of the level of impact of positive changes in these factors on the establishment of cooperation in the future in all analyzed sectors. In all cases high strength of correlations can be noticed.

\subsection{Companies cooperation with the sphere of science}

Respondents, especially those in the wood and furniture industry, assessed the level of their existing cooperation with scientific institutions as very low (see Table 5). Statistically significant differences were noticed between the opinions of wood and furniture companies and metal and machine and food companies. In all the analyzed sectors as well as in the surveyed companies generally the dominant proportion of respondents stated that so far no cooperation as been undertaken with $\mathrm{R} \& \mathrm{D}$ institutions (dominant at level 1). Apart from the metal and machine industry there is a very strong differentiation of respondents' ratings. It is important to note that in Podlaskie region the level of industrial development is low in comparison to other regions of the country, which further enhances the adverse balance in the field of cooperation between science and business (Nazarko, \& Kononiuk, 2013; Radziszewski, Nazarko, Vilutiene, Dębkowska, Ejdys et al., 2016) and, in turn, demands developments of the cooperation between business and local authorities (Hajduga et al., 2018).

The poor cooperation of companies with the sphere of science was already indicated in Polish publications a decade ago. They highlighted the poor level of cooperation between the two spheres (MRR, 2006; MNiSW, 2006). In comparison to other EU countries it has also been assessed as very low by the World Economic Forum (ZDSP, 2008). Unfortunately, this unfavorable situation has not improved over the past years. As indicated by J. Różański (2016, p. 4) less than $24 \%$ of the enterprises surveyed by him declared their frequent contacts with universities, $15.6 \%$ with industrial research institutions and $14.4 \%$ with R\&D units. The Central Statistical Office data show, however, that in 2012-2014 only about $17 \%$ of industrial enterprises indicated cooperation with higher education institutions as particularly advantageous (in 2015-2017 - 24.4\%). Research institutes were indicated by $14.3 \%$ of the companies (in 2015-2017 - 15.9\%) and scientific units of the Polish Academy of Sciences by less than 2\% (in 2015-2017-1.0\%) (GUS 2015, p. 104; GUS 2018, p. 87). The results of A. Sopińska and P. Wachowiak's (2016, p. 20) survey also indicated low use of universities and research institutions as a source of innovation. Only $17.6 \%$ of the managers researched by them indicated entities of science as an external source of innovation.

Slightly more optimism in regard to cooperation with the institutions of science, however there is still leaving a lot to be desired, is noticeable in the respondents' declarations about the near future. Although the average ratings in various industries slightly differ from each other, the conducted Kruskal-Wallis test indicates that the differences are statistically insignificant. And although the differentiation in the ratings is lower than in the case of current cooperation, it is still present on a high level. The conducted Spearman' ranks correlation indicates a high dependency between the ratings of current cooperation and the 
possibility of increasing it in the next 2-3 years. The higher the respondents assessed the current level of their cooperation with these institutions, the bigger readiness to strengthen it in the future they declared. This is the right line of action. The increase in innovativeness of Polish enterprises is necessary so that they can be competitive in the market, both domestic and international (e.g.: Ejdys, 2014; Ejdys, Ustinovicius, \& Stankevičiené, 2015). It will not be possible without cooperation between business and the sphere of science.

Table 5. Current and future cooperation whit science sphere institutions in the respondents' opinion

\begin{tabular}{lcccc}
\hline Specification & $\bar{x}$ & $M_{e}$ & $D$ & $V$ \\
\hline \multicolumn{1}{c}{ Declared level of cooperation with science sphere institutions / Degree of interest in strengthening } \\
& \multicolumn{5}{c}{ cooperation } & within the next 2-3 years \\
\hline Companies in total & $2.51 / 3.20$ & $2.00 / 3.00$ & $1 / 3$ & $62.05 / 52.00$ \\
Food companies & $2.66 / 3.05$ & $2.00 / 3.00$ & $1 / 3$ & $60.18 / 51.97$ \\
Metal and machine companies & $2.76 / 3.42$ & $3.00 / 3.00$ & $1 / 2$ & $54.76 / 52.99$ \\
Wood and furniture companies & $1.93 / 2.71$ & $1.00 / 3.00$ & $1 / 1 ; 3$ & $64.10 / 54.91$ \\
Construction companies & $2.38 / 3.07$ & $2.00 / 3.00$ & $1 ; 2 / 3$ & $62.08 / 50.06$ \\
\hline
\end{tabular}

Correlation of Spearman's rank ( $\mathrm{p}<0.05$ )

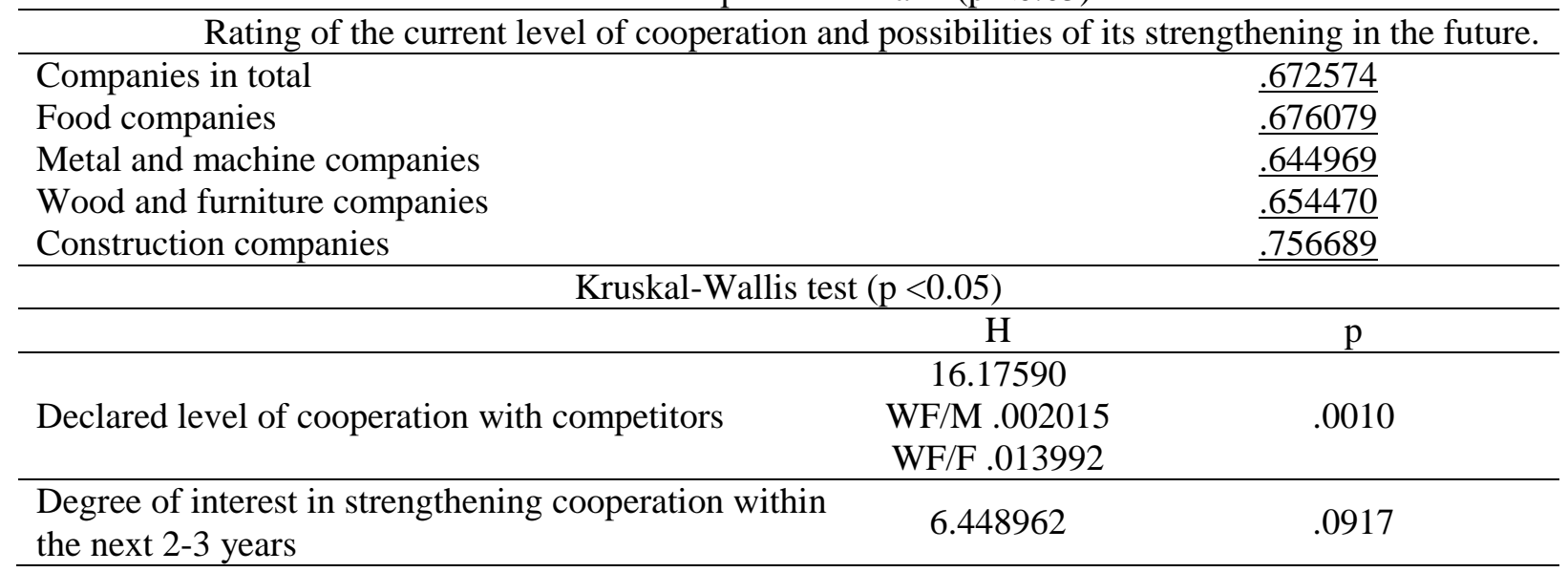

Source: own study

The most common area of establishing cooperation by respondents with institutions of science was primarily help in improving employees' qualifications, help with resolving technological problems and the transfer of knowledge (see Table 6). It seems that universities fulfill this role particularly well since today they not only play the role ofresearch centres that are merely teaching facilities, but are also the institutions providing the education process that will be used in the future economy. Poorly rated area of undertaking cooperation between both spheres was help with resolving organisational problems. On the one hand this may be due to a lack of conviction of many entrepreneurs of the significance of the impact of these problems on the efficiency of their businesses' operation and therefore if something is unimportant it is not worth investing any financial resources and time in solving it. Meanwhile on the other hand, many members of top management are convinced of their sufficient knowledge in order to solve such problems (Wasiluk, 2016). 
Table 6. Descriptive statistics for theratings of the impact of various factors on the level of existing cooperation with science sphere institutions and of positive changes in various factors on the level of cooperation in the near future

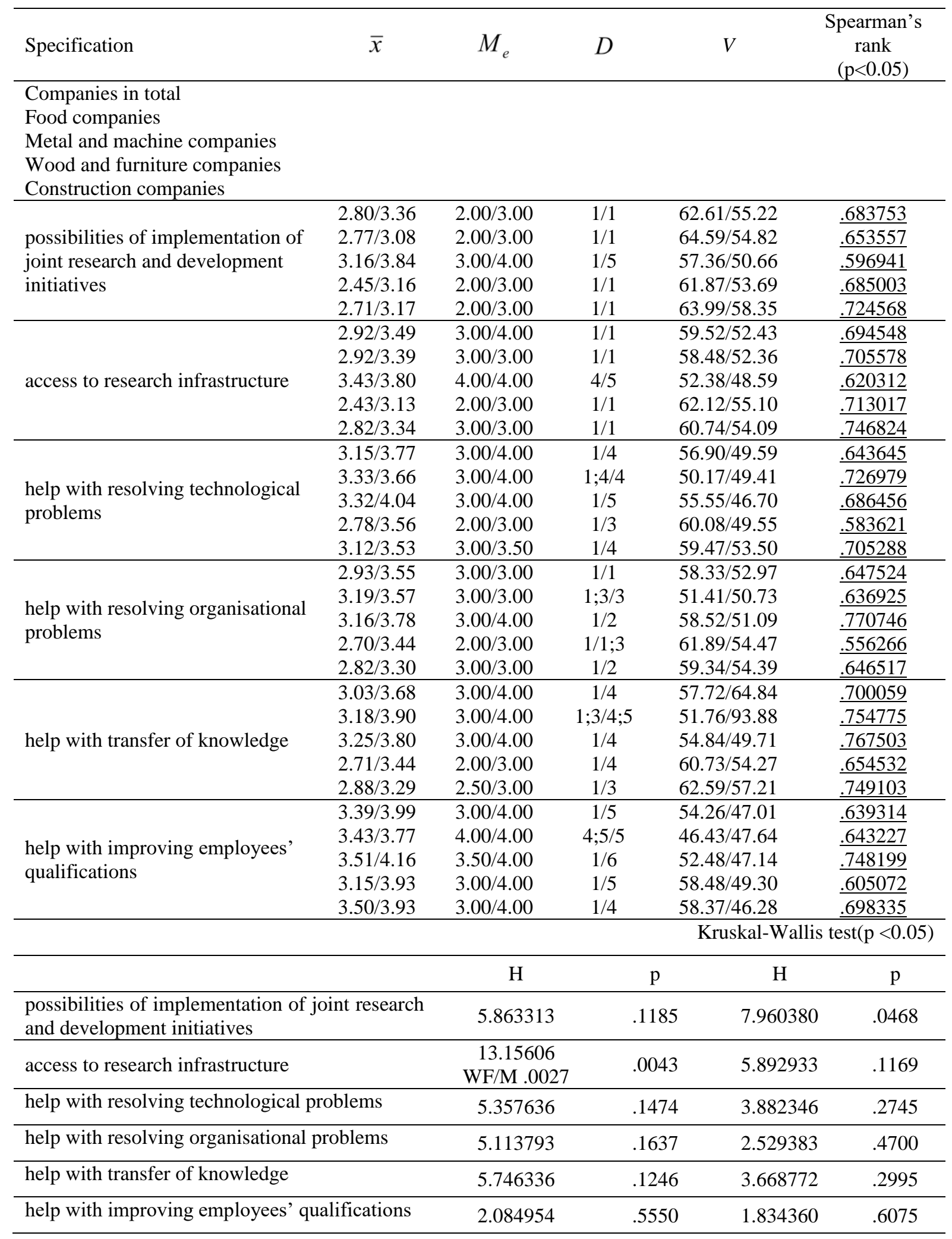

Source: own study 
The possibility of undertaking common research and development initiatives was also rated very poorly. In the case of this factor in all analysed sectors as well as for all surveyed enterprises, the dominant amounted to 1 . This means that the highest percentage of respondents in general have not cooperated in this regard. On the one hand this is certainly due to the fact that a lot of Polish companies never undertake such activities, as mentioned earlier in this text, and on the other hand this may be due in part to the stereotype of the scientist as a person detached from reality who creates only theories. And for most entrepreneurs, that which is theoretical is automatically impractical.

Kruskal-Wallis' test indicates the presence of statistically significant differences between the opinions of companies from the wood and furniture and metal and machine industries only in regard to access to research infrastructure as a condition for undertaking cooperation. Analysis of the value of the variation coefficient allows us to determine the presence of a strong differentiation of respondents' ratings across the same sector.

In the opinion of many respondents positive changes in all the identified areas of undertaking cooperation can contribute to strengthening the cooperation in the near future. However, a significant percentage of the surveyed companies do not intend to contact the sphere of science in the next 2-3 years. Bearing in mind that the good experience of the past cooperation result in a habit and conviction as to the reliability of the partners as for their compliance with obligations (Braun 2010, p. 229) they should seek to initiate such contacts. On the one hand we need to break the stereotype of a scientist as a person completely detached from reality, who conducts research which no one needs and on the other hand strive to improve business awareness of the need for learning throughout life, improving knowledge and valuing the specific benefits of lifelong learning. Non-existing cooperation with institutions of science was also reflected in the low ratings of possibilities to influence positive changes in the analysed factors in the future.

Average ratings in individual sectors slightly differ from one another; however, as the Kruskal-Wallis test indicates these differences are not statistically significant. An analysis of the value of the coefficient of variation allows us to determine the presence of a strong and in the case of ratings by food companies in regard to help in the transfer of knowledge even very strong, diversity of respondents' ratings across the same sector.

A positive correlation was noticed between the ratings of influence of various conditions on the existing cooperation with institutions of science and the assessment of possibilities for improving it in the future in case of occurrence of positive changes in these areas.

The Spearman' rank correlation conducted for ratings of the surveyed companies leads to the conclusion that the increase in ratings of the level of impact of individual factors on the current level of cooperation is accompanied by an increase in the average value of the ratings of the level of impact of positive changes in these factors on the establishment of cooperation in the future, in all analysed sectors. In all cases we can talk about high strength of correlations.

\subsection{Dependencies in the rankings of the current and future cooperation between the different spheres}

It seemed interesting to examine whether there was a correlation between the ratings of cooperation in one of the analysed areas with the ratings of cooperation with another? Do the companies which rated their current cooperation with competitors highly also rate highly their cooperation with institutions of science and business environment institutions? Do the respondents who rated their cooperation with the institutions of science highly also rated higher their cooperation with business environment institutions? 

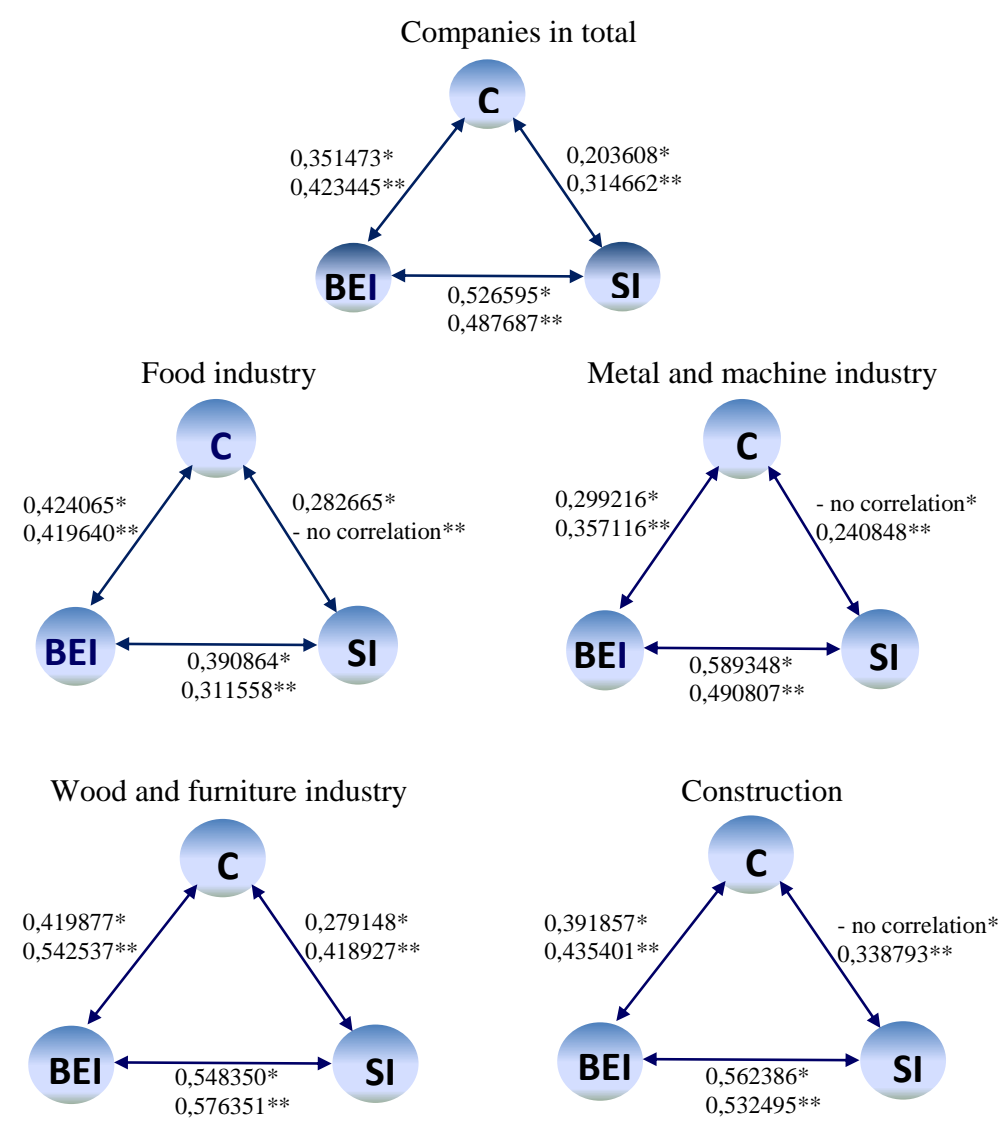

$\mathrm{C}$ - cooperation with competition; SI - cooperation with scientific institutions; BEI - cooperation with business environment institutions. *Spearman's rank correlation for ratings of cooperation between A \& B spheres

**Spearmen's rank correlation for ratings of interest in strengthening cooperation between A \& B spheres

Figure 1. Spearman's rank correlation between the ratings of current and future cooperation in different spheres (Spearman's rank $\mathrm{p}<0.05$ )

Source: own study.

The conducted analysis allows us to notice that the strongest correlations exist between the ratings of current cooperation and also readiness to strengthen it in the near future, in regard to the sphere of science and business environment institutions (with the exception of respondents from the food industry). Therefore, we can conclude that the higher the respondents rated their cooperation (current and future) with the sphere of science, the higher they rated it also with business environment institutions. The strength of these correlations is at a moderate level, so we can talk about significant dependence. However, in the case of companies in the food industry the strongest correlations were between the ratings of cooperation (present and future) with competing companies and business environment institutions. Thus, the higher these companies rated their cooperation with competitors the higher they rated it also with business environment institutions. However, it should be noted that the strength of these dependencies was also at a moderate level.

A low or even non-existent dependency between ratings can be stated in the case of ratings regarding cooperation (current and future) with competing firms and entities of the sphere of science. The only exception is the strength of Spearman's rank correlation for ratings regarding future cooperation of the respondents in the wood and furniture industries, which indicates a significant correlation. Therefore it should be stated that the higher the 
respondents rated the possibility of strengthening their cooperation with competing firms the higher they rated such a possibility with scientific institutions.

\section{Conclusion}

The modern economy demands a new approach to cooperation processes from modern businesses. One of the methods of coping with an uncertain environment is through cooperation, allowing entities to, among others, aggregate resources, reduce costs, increase elasticity and adaptability to new environments and so on. Cooperation is realised through various configurations of relations between partners. As mentioned earlier, a specific form of inter-organisational cooperation is clusters, defined as networks of entities interacting with one another, based on social and business relations. In subject literature authors often point out the pro-innovative character of these structures as one of their advantages. Keeping in mind the low levels of innovation in Polish businesses, the development of cluster structures seems to be highly desirable. An increase in the innovation of Polish businesses is necessary in order for them to become competitive in the national and international market. Cooperation between entities of different spheres plays a significant, if not deciding role both in creating and in developing cluster structures. Here we have in mind active and practical forms of cooperation between members of each cluster. Without a readiness of entities to undertake cooperation, efforts aimed at developing these structures are doomed to fail from the very beginning (Jirčiková, Pavelková, Bialic-Davendra, \& Homolka, 2013).

In conclusion, the research carried out has allowed us to specify previous academic achievements with regard to the readiness of companies to undertake cooperation with their competition and with scientific institutions and business environment entities. The obtained results indicate a large deficit both in terms of previous cooperation and with regard to the readiness to increase it in the near future, which unfortunately confirms previous conclusions in literature. As mentioned above, this kind of cooperation is a necessary condition in forming effective cluster structures, whose benefits include, among others, increasing the innovative potential of firms as well as their competitiveness. In these conditions it is difficult to speak of real possibilities of creating and developing effective cluster structures that are able to compete on the global market. If the situation does not improve, networks will play only a local role.

Finally, it must be underlined that although the study carried out contributed towards filling in the existing gaps in research regarding the cooperation of companies with other competing firms and with scientific institutions and business environment institutions in a regional scope, it is not free from certain restrictions, stemming from the methodological approach that was used and resulting above all in a lack of ability to generalise the results. This is part of the reason for which an additional direction of academic research could be undertaking a replication of this study on a representative and national scale, in companies in Poland. 


\section{References}

Adekola, A., Korsakiene, R., \& Tvaronavičiene, M. (2008). Approach to innovative activities by Lithuanian companies in the current conditions of development. Technological and Economic Development of Economy, 14(4), 595-611. http://dx.doi.org/10.3846/13928619.2008.14.595-611

Adler, P.S., \& Kwon, S.-W. (2014). Social Capital: Maturation of a field of research. Academy of Management Review, 39(4), 412-422. http://dx.doi.org/10.5465/amr.2014.0210

Antonelli, C. (1992). The economic theory of information networks. In: C. Antonelli (Ed.) The Economics of Information Networks, 5-27. Amsterdam: Elsevier Science.

Baczko, T. (2012). Raport o innowacyjności gospodarki Polski w 2012 roku [Report on the innovativeness of the Polish economy in 2012]. Warszawa: Instytut Nauk Ekonomicznych PAN.

Bąkowski, A., \& Mażewska, M. (Eds.). (2015). Ośrodki innowacji i przedsiębiorczości w Polsce. Raport 2014 [Innovativeness and Entreprenuership Centres in Poland. Report 2014]. Poznań-Warszawa: SOOIiP w Polsce.

Benneworth, P., Schulze-Greiving, V., \& Konrad, K. (2019). Knowledge bases and responsibility within regional innovation systems: reflections from the Twente region. European Planning Studies, 27(12), 2491-2509. doi: 10.1080/09654313.2019.1635086

Bilan, Y., Mishchuk, H., \& Dzhyhar, T. (2017). Human capital factors and remuneration: analysis of relations, modelling of influence. Business: Theory and Practice, 18, 208 214. https://doi.org/10.3846/btp.2017.022

Bilan, Y., Mishchuk, H., Samoliuk, N., \& Grishnova, O. (2019). ICT and Economic Growth: Links and Possibilities of Engaging. Intellectual Economics, 13(1). https://doi.org/10.13165/IE-19-13-1-07

Braumberger, A. (2019). Lider innowacji? Raport KE ukazuje żenujaca prawdę o polskiej gospodarce [Leader of Innovation? The EC report reveals the embarrassing truth about the Polish economy]. Retrieved November 7, 2019 from https://spidersweb.pl/bizblog/europejski-ranking-innowacyjnosci-2019/

Braun, S. (2010). Gemeinschaftsbeziehungen, Vertrauen und Reziprozitätsnormen. In: M. Maring (Ed.), Vertrauen - zwischen sozialem Kitt und der Senkung von Transaktionskosten, 223-238. Karlsruhe: KIT Scientific Publishing.

Bromski, K. (Ed.). (2013). Wspótpraca nauki i biznesu. Doświadczenia i dobre praktyki wybranych projektów w ramach Programu Operacyjnego Innowacyjna Gospodarka na lata 2007-2013 [Cooperation of science and business. Experiences and good practices of selected projects under the Innovative Economy Operational Program 2007-2013]. Warszawa: PARP.

Cai, Y. (2015). What contextual factors shape 'innovation in innovation'? Integration of insights from the Triple Helix and the institutional logics perspective. Social Science Information, 54(3), 299-326. doi: 10.1177/0539018415583527

Chick, S.E., Huchzermeier, A., \& Netessine, S. (2014). Europe's solution factories. Harvard Business Review, 92(4), 111-115.

Czakon, W. (2007). Dynamika więzi międzyorganizacyjnych przedsiębiorstwa [The dynamics of company interorganizational ties]. Katowice: Wydawnictwo Akademii Ekonomicznej w Katowicach.

Czakon, W. (2012). Sieci $w$ zarzadzaniu strategicznym [Networks in strategic management].Warszawa: Oficyna a Wolters Kluwer business. 
Daniluk, A. (2016). Conditions of cooperation between enterprises and business environment institutions using the Podlasie region as an example. Engineering Management in Production and Services, 8(4), 18-27. doi: 10.1515/emj-2016-0029

Daniluk, A., \& Tomaszuk, A. (2016). Cooperation between competing companies as factor of technological entrepreneurship creation, Proceeding of Selected Papers, Smart and Efficient Economy: Preparation for the Future Innovative Economy, 21 th International Scientific Conference: Economics and Management 2016, 533-541.

Daniluk, A. (2018). Proinnowacyjne przesłanki podejmowania współpracy przez przedsiębiorstwa [Pro-innovativepremises for undertakingcooperation by enterprises]. In: P. Wachowiak, \& S. Gregorczyk (Eds.), Organizacja kreatywna. Teoria i praktyka [Creative organization. Theory and practice], 185-197. Warszawa: Oficyna Wydawnicza Szkoła Główna Handlowa w Warszawie.

Dobrzyński, M., Dziekoński, K., \& Jurczuk, A. (2013). Ocena skłonności do kooperacji przy realizacji procesów biznesowych w klastrze [Evaluation of willingness to cooperate in the implementation of business processes in a cluster]. International Journal of Contemporary Management, 2, 76-81.

Ejdys, J. (2014). Future oriented strategy for SMEs. Procedia - Social and Behavioral Sciences, 156, 8-12. https://doi.org/10.1016/j.sbspro.2014.11.110

Ejdys, J. (2015). Innovativeness of residential care services in Poland in the context of strategic orientation, Procedia - Social and Behavioral Sciences, 213, 746-752. doi: 10.1016/j.sbspro.2015.11.461

Ejdys, J., Ustinovicius, L., \& Stankevičienè, J. (2015). Innovative application of contemporary management methods in a knowledge-based economy interdisciplinarity in science, Journal of Business Economics and Management, 16(1): 261-274. doi:10.3846/16111699.2014.986192

Elexa L., Lesáková L., Klementová V., \& Klement L. (2019). Identification of prospective industrial clusters in Slovakia. Engineering Management in Production and Services, 11(2), 31-42. doi: 10.2478/emj-2019-0009

European Commission. (2010). Europe 2020. A strategy for smart, sustainable and inclusive growth, Brussels 3.3.2010.

European Commission. (2016). European Innovation Scoreboard 2016. Retrieved January 3, 2019 from http://ec.europa.eu/DocsRoom/documents/18062

Fawcett, S.E., Magnan, G.M., \& McCarter, M.W. (2008). Benefits, barriers, and bridges to effective supply chain management. Supply Chain Management: An International Journal, 13(1), 35-48. doi: 10.1108/13598540810850300

Garanti, Z., \& Zvirbule-Berezina, A. (2013). Regional cluster initiatives as a driving force for regional development. European Integration Studies, 7, 91-101. http://dx.doi.org/10.5755/j01.eis.0.7.3677

Gnyawali, D.R., \& Park, B.-J.(R.). (2009). Co-opetition and Technological Innovation and Medium-Sized Enterprises: A Multilevel Conceptual Model. Journal of Small Business Management 47(3), 308-330. doi: 10.1111/j.1540-627X.2009.00273.x

Gorynia, M., \& Jankowska, B. (2008). Klastry a międzynarodowa konkurencyjność $i$ internacjonalizacja przedsiębiorstwa [Clusters and the international competitiveness and internationalization of the enterprise]. Warszawa: Difin.

Gryczka, M. (2017). Struktura nakładów na B+R a innowacyjność gospodarki na przykładzie wybranych krajów [Structure of expenditure on R\&D and economic innovation on the example of selected countries]. Studia $i$ Prace WNEiZ, 49, 297-316. http://dx.doi.org/10.18276/sip.2017.49/2-22

GUS. (2015). Działalność innowacyjna przedsiębiorstw $w$ latach 2012-2014 [Innovation activities of companies in 2012-2014]. Warszawa: Główny Urząd Statystyczny. 
GUS. (2016). Działalność innowacyjna przedsiębiorstw w latach 2013 - 2015 [Innovation activities of companies in 2013 - 2015]. Warszawa: Główny Urząd Statystyczny.

GUS. (2018). Działalność innowacyjna przedsiębiorstw w latach 2015 - 2017 [Innovationactivities of companies in 2015 - 2017]. Warszawa: Główny Urząd Statystyczny.

Hajduga, P., Pilewicz, T., \& Mempel-Śnieżyk, A. (2018). Cooperation between local authorities and economic entities in Polish economic zones-evidence from Lower Silesia in Poland. Economics \& Sociology, 11(2), 80-96.

Hao, Z., Qi, W., Gong, T., Chen, L., \& Shen, Z-J. M. (2019). Innovation uncertainty, new product press timing and strategic consumers. Omega International Journal of Management Science, 89, 122-135. doi: 10.1016/j.omega.2018.09.011

Hemert, P. V., Nijkamp, P., \& Masurel, E. 2012. From Innovation to Commercialization Through Networks and Agglomerations: Analysis of Sources of Innovation, Innovation Capabilities and Performance of Dutch SMEs, The Annals of Regional Science, 49(1), 1-28. doi: 10.1007/s00168-010-0431-3

Jirčiková, E., Pavelková, D., Bialic-Davendra, M., \& Homolka, L. (2013).The age of clusters and its influence on their activity preferences. Technological and Economic Development of Economy, 19(4), 621-637. doi/10.3846/20294913.2013.837115

Kale, P., Dyer, J.H., \& Singh, H. (2002). Alliance Capability, Stock Market Response and Long-term Alliance Success. The Role of the Alliance Function. Strategic Management Journal, 23(8), 747-767. doi: 10.1002/smj.248

Karbowski, A. (2019). Cooperative and non-cooperative R\&D in product innovation and firm performance. Journal of Business Economics and Management, 20(6), 1121-1142. https://doi.org/10.3846/jbem.2019.11050

Kijkuit, B., \& van den Ende, J. (2010). With a Little Help from Our Colleagues: A Longitudinal Study of Social Networks for Innovation. Organization Studies, 31(4), 451-479. doi: 10.1177/0170840609357398

Kim, C.-S., Dinwoodie, J., \& Seo, Y.J. (2018). Inter-Firm Cooperation and Collaboration in Shipper-Shipping Company Relationships for Enhancing Sustainability. Sustainability 10(10), article number: 3714. doi: 10.3390/su10103714

Kirikkaleli, D., \& Ozun, A. (2019). Innovation capacity, business sophistication and macroeconomic stability: empirical evidence from OECD countries. Journal of Business Economics and Management, 20(2), 351-367. https://doi.org/10.3846/jbem.2019.9602

Klimas, P. (2015). Przesłanki i bariery zawiązywania więzi międzyorganizacyjnych [Prerequisites and barriers to establishing cross-organizational ties]. Problemy Zarzadzania, 13(1), 29-46.

Kowalski, A.M. (2010). Rola klastrów w intensyfikacji współpracy nauki z gospodarką [The role of clusters in the intensification of cooperation between science and economy]. In M.A. Weresa (Ed.), Polska. Raport o konkurencyjności 2010. Klastry przemystowe a przewagi konkurencyjne [Poland. Competitiveness Report 2010. Industrial Clusters vs. Competitive Advantages].Warszawa: Instytut Gospodarki Światowej SGH.

Kozłowski, R., \& Matejun, M. (2012). Współpraca międzyorganizacyjna w zarządzaniu projektami małych i średnich przedsiębiorstw [Inter-organizational cooperation in project management for small and medium enterprises]. Przegląd Organizacji 6, 35-38.

KPMG. (2014). Dojrzałość innowacyjna przedsiębiorstw w Polsce [Innovative maturity of enterprises in Poland]. Retrieved February 10, 2019 from https://kpmglegal.pl/wpcontent/uploads/2014/07/Dojrzalosc-innowacyjna-przedsiebiorstw-w-Polsce-KPMG2014.pdf 
Lašáková, A., Bajzíková, L'ubica, \& Blahunková, I. (2019). Values oriented leadership conceptualization and preliminary results in Slovakia.Business: Theory and Practice, 20, 259-269. https://doi.org/10.3846/btp.2019.25

Leonidou, L.C., Barnes, B.R., \& Talias, M.A. (2006). Exporter - importer relationship quality: The inhibiting role of uncertainty, distance, and conflict, Industrial Marketing Management, 35(5), 576-588. doi:10.1016/j.indmarman.2005.06.012

Lin, E.S., Hsiao, Y.-Ch., \& Lin, H.-I. (2013). Complementarities of R\&D strategies on innovation performance: Evidence from Taiwanese manufacturing firms. Technological and Economic Development of Economy, 19 (sup 1), S.134-156. doi:10.3846/20294913.2013.876684

Lis, A.M. (2018). Współpraca w inicjatywach klastrowych. Rola bliskości w rozwoju powiązań kooperacyjnych [Cooperation in clusterinitiatives. The role of proximity in the development of cooperative relationships]. Gdańsk: Wydawnictwo Politechniki Gdańskiej.

Lis, A. M. (2019). The significance of proximity in cluster initiatives. Competitiveness Review: An International Business Journal, 29(3), 287-310.

Moczydłowska, J.M., Korombel, A., \& Bitkowska, A. (2017). Relacje jako kapitał organizacji [Relations as the capital of the organization]. Warszawa: Difin.

Myšková, R., \& Kuběnka, M. (2019). Information sharing in the context of business cooperation-as a source of competitive advantage. Journal of International Studies, 12(3).

Nazarko, J., \& Chodakowska, E. (2017). Labour efficiency in construction industry in Europe based on frontier methods: data envelopment analysis and stochastic frontier analysis. Journal of Civil Engineering and Management, 23(6), 787-795, doi: 10.3846/13923730.2017.1321577.

Nazarko, J., \& Kononiuk, A. (2013). The critical analysis of scenario construction in the polish foresight initiatives. Technological and Economic Development of Economy, 19(3), 510-532. doi: 10.3846/20294913.2013.809030

Nazarko, J. (2013). Regionalny foresight gospodarczy. Scenariusze rozwoju innowacyjności mazowieckich przedsiębiorstw [Regional economic foresight. Scenarios of the innovation-oriented development of Mazovian enterprises]. Warszawa: ZPWiM.

Nguyen, H.L., Larimo, J., \& Wang, Y. (2019). Control, innovation and international joint venture performance: The moderating role of internal and external environments. International Business Review, 28(6). doi: 10.1016/j.ibusrev.2019.101591

Nowak, D. (2015). Bariery rozwoju relacji kooperacyjnych [Barriers to the development of cooperative relations], Problemy Zarzadzania 13(1): 47-67.

Oláh, J., Karmazin, G., Fekete, M. F., \& Popp, J. (2017). An examination of trust as a strategical factor of success in logistical firms. Business: Theory and Practice, 18, 171177. https://doi.org/10.3846/btp.2017.018

PARP. (2015). Innowacyjna przedsiębiorczość w Polsce. Odkryty i ukryty potencjał polskiej innowacyjności. Raport [Innovative Entrepreneurship in Poland. Open and hidden potential of Polish innovation. Report], Polska Agencja Rozwoju Przedsiębiorczości, Warszawa.

Radziszewski, P., Nazarko, J., Vilutiene, T., Dębkowska, K., Ejdys, J., Gudanowska, A., Halicka, K., Kilon, J., Kononiuk, A., Kowalski, K.J., Krol, J.B., Nazarko, L., \& Sarnowski, M. (2016). Future trends in road pavement technologies development in the context of environmental protection. Baltic Journal of Road and Bridge Engineering, 11(2), 160-168. doi: 10.3846/bjrbe.2016.19 
Raišienè, A. G., Bilan, S., Smalskys, V., \& Gečienė, J. (2019). Emerging changes in attitudes to inter-institutional collaboration: the case of organizations providing social services in communities. Administratie si Management Public, (33), 34-56.

Romanowska, M. (2016). Determinanty innowacyjności polskich przedsiębiorstw [Determinants of innovativeness of Polish enterprises]. Przeglad Organizacji, 2, 29-35.

Roy, S., Sivaramakrishnan, K., \& Wilkinson, I.F. (2004). Innovation Generation in the Supply Chain Relationships. A Conceptual Model and Research Propositions. Journal of the Academy of Marketing Science, 32(1), 61-79. doi: 10.1177/0092070303255470

Różański, J. (2016). Innowacje w globalizującej się gospodarce [Innovation in a globalizing economy]. Przeglad Organizacji, 6, 4-9.

Ryciuk, U. (2016). Zaufanie międzyorganizacyjne $w$ tańcuchach dostaw $w$ budownictwie [Cross-organizational trust in supply chains in the construction industry]. Warszawa: PWN.

Rzepka, A. (2017). Inter-organizational relations as a one of sources of competitive advantage of contemporary enterprises in the era of globalization. Procedia Engineering, 174, 161-170. doi: 10.1016/j.proeng.2017.01.195

Rzepka, A. (2019). Innovation, inter-organizational relation, and co-operation between enterprises in Podkarpacie region in Poland. Procedia Manufacturing, 30, 642-649. doi: 10.1016/j.promfg.2019.02.091

Schermerhorn, I. (1975). Determinants of Interorganizational Cooperation. Academy of Management Journal, 18(4), 846-856.

Sopińska, A., \& Wachowiak, P. (2016). Innowacyjność przedsiębiorstw działających w Polsce [Innovativeness of companies operating in Poland]. Przegląd Organizacji, 5, 17 23.

Stańczyk-Hugiet, E., \& Strzelecka, R. (2015). Relacje strategiczne przedsiębiorstw deweloperskich [Strategic relationships between developers]. Problemy Zarzadzania, 13(1), 68-87.

Stanisławski, R. (2016). Zasoby relacyjne instytucji otoczenia biznesu w kontekście rozwoju innowacyjnego małych i średnich przedsiębiorstw [Relational resources of business environment institutions in the context of innovative development of small and medium enterprises]. Przeglad Organizacji, 6, 9-18.

Stein, H.D., \& Ginevičius, R. (2010). Overview and comparison of profit sparing In different business collaboration forms. Journal of Business Economics and Management, 11(3), 428-443. http://dx.doi.org/10.3846/jbem.2010.21

Tidd, J., Bessant, J. (2013). Managing Innovation. Integrating Technological, Market and Organizational Change. Chichester: John Wiley \&Sons.

UMWP. (2013). Strategia Rozwoju Województwa Podlaskiego do roku 2020 [Development Strategy for Podlaskie Province until 2020]. Białystok: Urząd Marszałkowski Województwa Podlaskiego.

Un, C.A., Romero-Martinez, A.M., \& Montoro-Sanchez, A. (2009). Determinants of R\&D Collaboration of Service Firms. Service Business, 3, 373-394. doi: 10.1007/s11628-0090065-7

Vaiciukevičiūtè, A., Stankevičienè, J., \& Bratčikovienė, N. (2019). Higher education institutions' impact on the economy. Journal of Business Economics and Management, 20(3), 507-525. https://doi.org/10.3846/jbem.2019.10156

van Dijk, M.P.; \& Sverrisson, Á. (2003). Enterprise clusters in developing countries: mechanisms of transition and stagnation. Entrepreneurship \& Regional Development, 15(3), 183-206. http://dx.doi.org/10.1080/08985620210159239

Wasiluk, A. (2013). Mutual trust between companies and cluster formation and development. Actual Problems of Economics, 147(9), 255-263. 
Wasiluk, A. (2017). Pro-innovative Prerequisites for Establishing the Cooperation between Companies (in the Perspective of Creation and Development of Clusters). Procedia Engineering, 182, 755-762.

Wasiluk, A. (2016). Trust and areas of cooperation between companies and institutions of science. Proceeding of Selected Papers, Smart and Efficient Economy: Preparation for the Future Innovative Economy 21th International Scientific Conference: Economics and Management 2016, 629-636.

Wasiluk, A. (2015). Zaufanie we współczesnym zarządzaniu [Trust in modern management]. In A. Kowalczewska (Ed.), Wybrane zagadnienia miękkiego zarządzania organizacjami [Selected issues of soft management of companies], 57-77. Warszawa: Ementon.

Widelska, U., Michalczuk, G., \& Moczydłowska, J.M. (2014). Competition and cooperation as determinants of relational capabilities companies in electronic trade and services sector (based on the example of the Podlaskie province). Economy \& Business, 8, 742751.

Wojnicka, E. (2004). System innowacyjny Polski z perspektywy przedsiębiorstw [Polish Innovation System in companies' perspective]. Gdańsk: IBnGR.

ZDSP. (2008). Raport o Kapitale Intelektualnym Polski [Report on the Intelectual Capital of Poland]. Warszawa: Zespół Doradców Strategicznych Premiera.

Zeng, S.X., Xie, X.M., \& Tam, C.M. (2010). Relationship between Cooperation Networks and Innovation Performance of SMEs. Technovation, 30(3), 181-194. http://dx.doi.org/10.1016/j.technovation.2009.08.003 